when required. Also, just as the vibrating sticks can be timed to one another by sliding weights along them, so the viorating electric meters can be regulated to one another, so that all shall indicate the same value for the same current, by changing the po ition or weight of the bobs attached to the vibrating arm.

The other meter of this class, Dr. Hopkinson's, depends on the fact that centrifugal force is proportional to the square of the angular velocity. He therefore allows a little motor to drive a shaft faster and faster, until centrifugal force overcomes electromagnetic attraction, when the action of the motor ceases. The number of turns of the motor is a measure of the quantity of electricity that has passed.

I will now pass on to the measurement of power transmitted by belting. The transmission of power by a strap is familiar to every one in a treadle sewing-machine or an ordinary lathe. The driving force depends on the difference in the tightness of the two sides of the belt, and the power transmitted is equal to this difference multiplied by the speed; a power-meter must, therefore, solve this problem-it must subtract the tightness of one side from the tightness of the other side, mulriply the difference by the speed at every instant, and add all the products together, continuously representing the growing amount on a dial. I shall now show for the first time an instrument that I bave devised, that will do all this in the simplest possible manner. I have here two wheels connected by a driving band of indiarubber, round which I have tied every few inches a piece of white silk ribbon. I shall turn one a little way, and hold the other. The driving force is indicated by a difference of stretching, the pieces of silk are much further apart on the tight side than they are on the loose. I shall now turn the handle and cause the wheels to revolve; the motion of the band is visible to all. The indiarubber is travelling faster on the tight side than on the loose side, nearly twice ai fast; this must be so, for as there $i$ i le $s$ material on the tight side than on the loose, there would be a gradual accumulation of the indiarubber round the driven pulley, if they travelled at the same speed; since there is no accumulation, the tight side must travel the faste.t. Now it may be shown mathematically that the difference in the speeds is proportional $\mathrm{b}$, th to the actual speed and to the driving strain ; it is therefore a measure of the power cr work being transmitted, and the difference in the distance travelled is a measure of the work done. I have here a working machine which shows directly on a dial the amount of work done; this I will show in action directly. Instead of indiarubber, elastic steel is used. Since the driving-pulley has the velocity of the tight side, and the driven of the loose side of the belt, the difference in the number of their turns, if they are of equal size, will measure the work. This difference I measure by differential gearing which actuates a hand on a dial. I may turn the handle as fast as I please; the index does not move, for no work is being done. I may hold the wheel and produce a great driving strain; again the index remains at rest, for no work is being done. I now turn the handle quickly, and lightly touch the driven wheel with my finger. The resistance, small though it is, has to be overcome; a minute amount of work is being done, the index creeps round gently. I will now put more pressure on my finger, more work is being done, the index is moving faster; whether I increase the speed or the resi-tance the index turns faster; its rate of motion measures the power, and the distance it has moved, or the number of turns, measures the work done. That this is so I will show by an experiment. I will wind up in front of a scale a $7 \mathrm{lb}$. weight; the hand has turned one-third round. I will now wind a $28 \mathrm{lb}$. weight up the same height; the hand has turned four-thirds of a turn. There are other points of a practical nature with regard to this invention which I cannot now describe.

There is one other class of instruments which I have developed of which time will let me say very little. The object of this class of instruments is to divide the speed with which two registrations are being effected, and continuously record the quotient. In the instrument on the table two iron cones are caused to rotate in time with the registration; a magnetised steel reel hangs on below. This reel turns about, and runs up or down the cones until it finds a place at which it can roll at ease. Its position at once indicates the ratio of the speeds which will be efficiency, horse-power per hour, or one thing in terms of another. Just as the integrators are derived from the steering of an ordinary bicycle, so this instrument is derived from the double steering of the "Otto" bicycle.

Though I am afraid that I have not succeeded in the short time at my disposal in making clear all the points on which I have touched, yet $I$ hope that $I$ have done something to remove the very prevalent opinion that meters for power and electricity do not exist.

\section{THE PERMIAN SYSTEM IN RUSSIA I}

$A$ QUESTION which has during the last few years occupicd Russian geologists is whether the upper horizon of the " mottled marls," which were considered by Murchison as Permian, must be still regarded as such, or rather as a member of the Trias-an opinion strongly advocated by several eminent geologists in Russia. The question is a large one, the mottled marls being the most widely-spread member of Murchison's Permian formation in Russia, and covering it almost on the whole of the surface it occupies in Russia in Europe. Were the Triassic origin of the mottled marls an established fact, the whole aspect of a geological map of Russia would be changed, and so it was on the map published in 1870 by a late member of the Academy, M. Helmersen, and on the map of the western slope of the Ural Mountains by Prof. Meller. The question is thus the subject of much controversy, and a whole series of papers is devoted to it in the Memoirs of the Kazan Sociely of Naturalists and elsewhere. The last of this series is a paper by Prof. Stuckenberg, which states the present aspect of the question and enables us to summarise the controversy in its broad features.

Murchison's Permian system covers, as is known, no less than 6600 square miles in eastern Russia, from the province of Archangel in the north to that of Ufa in the south, and from Nijni-Novgorod in the west to Perm and Orenburg in the east ; isolated islands of it appear on the surface in the provinces of Astrakhan, Kharkov, and Ekaterinoslav. The evidence itself of the basin where the Permian formation was deposited necessarily implies a great variety of lithological characters, and in fact it includes, besides the dolomitic limestones, a very great variety of marls, clays, sandstones, and conglomerates, the limestones occupying separate basins in the middle parts, whilst the marls, clays, sandstones, and conglomerate: have the appearance of coast deposits of the Permian Sea.

In the central parts of the basin (Kazan, Samara), the dolomitic limestones are covered with a thick sheet of mottled marls, with sandstones, conglomerates, clays, and isolated thinner sheet of a tuff-like limestone. This series covers, however, not only the dolomitic limestone but also, as has been said, nearly the whole of the Permian deposits of European Russia, confounding itself with the Permian marls and sandstones, as is, for instance, the case-M. Stuckenberg say_-in the provinces of Vyatka, Nijni-Novgorod, Kazan, and Samara. Palæontological evidence, however, is scarce as to the upper mottled marls, so that Murchison himself made the suggestion that they may belong perhaps to a more recent formation; he even proposed to give them on his map a lighter colour than the remainder of the Permian formation.

The mottled marls were considered as Permian until I 855 , when Prof. Wagner published a geological map in which he classified them as Triassic. Later on, Marcou, in 1858, and Ludwig, in his "Dias and Trias," in 1859, arrived, independently of Prof. Wagner, at the same conclusion. In 1864 Prof. Barbot de Marny discovered in a sandstone belonging to this group a fragment of an Equisetites columnaris, Sternb. (Calamites arenaceus, Brongn.), and this discovery, confirming former stratigraphical and lithological considerations, induced the majority of Russian ge logists to consider since the mottled marls as a part of the Trias. This view was adopted, as said, by Helmersen and by Prof. Meller. But still, as the mottled marls are very poor in organic remains, and the whole question beset with difficulties, the controversy continued. Murchison found in these marls small Cytherince and shells like Cyclas, together with some remains of fishes and casts of Mytilus. Prof. Golovkinsky discovered microscopic remains of crustaceans and some fragments of shells, whilst the late M. Eichwald found remains of Estheria exigua and Beyrichia Pyrrha, in a deposit which M. Stuckenberg considers as belonging to the same group. As to the find by Prof. Wagner of the Voltzia heterophylla at Abdi, close by Mamadysh, together with remains of the fishes Amblypterus Alberti and Saurichthys Mougeoti, M. Stuckenberg

$x$ "The Upper Mottled Marls and their Relations to other Members of the Permian System," by A. Stuckenberg. (Memoirs of the Kazan Societ of Naturalists, vol. xi. fasc. 2 ; Kazan, I882. 
doubts, first, the accuracy of the determination, and adds that the Voltzia was not found in the mottled marls, but in deposits " parallel to the Permian limestone."

The Zechstein (dolomites, dolomitic limestones, oolite, and gypsum), which reaches a great thickness in the provinces of Kazan and Samara, is a formation which was contemporary with the Permian marls, sandstones, and conglomerates which are widely spread in the provinces of Kazan, Nijni, Vyatka, Perm, Ufa, and Orenburg. On the places where both meet together, the Zechstein penetrates in the shape of thinner sheets into the marls. The copper sandstones of the Ural also would be, according to the same author, contemporary with the Zechstein. These marls and sandstones bave a characteristic fauna, and MM. Stuckenberg and Zaitseff discovered in them the following fossils :-Lingula orientalis, Golovk. ; Unio umbonatus, Fisch. ; Unio castor, Eichw. ; Aucella Hausmanni, Goldf.; Estheria exioua, Eichw.; Beyrichia Pyrrha, Eichw.; and remains of ganoid fishes and lizards. These fossils are characteristic of the group, but it contains also the Zechstein fossils, Stenopora columnaris, Schl., Schizodus obscurus, Gein., Schizodus rossicus, Vern., Nucula Beyrichi, Bron., Murchisonia subangulata, Vern., Gervillia suicata, Gein., Gervillia seratophaga, Schl., Hinnites (Avicula) speluncaria, Schloth., Arca Kingiana, Vern., Clidophorus Pallasi, Vern., Terebratula elongata, Schl., Productus Cancrini, Vern., Camarophoria Schlotheimi, Buch., and Spirifer ruoulatus, Kut. The flora of this series is characterised by many Coniferæ (among others, the Uhlmannia Bronnii and brevifolia) Noeggerathiæ (expansa and cuneifolia), ferns, \&c. These deposits are thus Permian, and it is worthy of notice that they contain the Unio umbonatus and castor, the Estheria exigua, and the Beyrichia Pyrrha.

As to the upper mottled marls, which are precisely the subject of the controversy, there was discovered in them but a very few fossils, by MM. Krotoff and Stuckenberg, namely, the four just mentioned (Unio umbonatus, Unio castor, Estheria exigua, and Beyrichia Pyrrha), on the Volga at Tetushi, and the same in the Government of Vyatka, where the marls contain sheets of limestone; besides, M. Krotoff found Zechstein fos-ils, as Arca Kingiana, in the tuff-like limestone on the Volga, which M. Stuckenberg considers as belonging to the same series. Finally, there was discovered during a boring at Mount Bogdo (Astrakhan), in sandstones and conglomerates, a series of P'ermian fossils (Matica minima, Brown, Turbonila volgensis, Grolowk, Gervillia antiqua, Mün., Clidophorus Hollebeni, Clidophorus Pallasi, Vern., Schizodus rossicus, Vern., S. obscurus, Gein., Nucula Beyrichi, Brown, Leda speluncaria, Gein., and Hinnites (Avicula) speluncaria, Schloth. M. Stuckenburg, considering the Bogdo sandstones as contemporary with the upper mottled marls, gives to it great weight; but it must be observed that the contemporaneity of the Bogdo marls with the upper mottled marls of the Volga is all but established.

As to the palæontological evidence produced for considering the upper mottled marls as Triassic, namely, those found of the Triassic, Equisetites columnaris (Calamites arenaceus), Voltzia heterophylla, and Estheria minuta, M. Stuckenburg considers it unsatisfactory, and points out that the Voltzia heterophylla was found rather in Permian deposits ; and that Mr. Jones, in his "Monograph of the Fossil Estherix," considers the Estheria minuta of the Russian mottled marls as different from the E. minuta, Brongn., and rather like to the E. tenella of Jordan, which last belongs to the Permian and Carboniferous of Western Europe. As to the Calamites arenacenis, found by Barbot de Marny, F. Römer, in the last edition of his "Lethea geognostica," remarks that it is too badly preserved to be a decisive evidence. He concludes, therefore, that contrary to the opinion of almost all Russian geologists, that the mottled marls ought to be considered again as Permian. But, as seen from the above summary, it will be much more prudent to conclade that the whole question still remains open for further investigation.

\section{UNIVERSITY AND EDUCATIONAL INTELLIGENCE}

CAMBRIDGE. - The Rede Lecture was delivered on Tuesday in the Senate House by Prof. Huxley, the subject being "The Origin of the Existing Forms of Animal Life, Construction or Evolution ?" There were at least eleven hundred persons present, and amongst them nearly all the University dignitaries now in residence.

In the second part of the Natural Sciences Tripos sixteen men and one lady are placed in the first class; of this Mr. Harmer of King's College is distinguished in Zoology and Comparative Anatomy ; Mr. Reid of Cavendish College in Human Anatomy; and Mr. Sharrington of Caius College in Pbysiology.

Prof. Hughes has been elect ed to a Professorial Fellowship at Clare College.

Messrs. P. Frost, I. Todhunter, and Joseph Wolstenholme are to receive the degree of Doctor in Science.

The Woodwardian Professor dissents strongly from the proposal to place the Sedgwick Museum on the Downing Street site in front of the new nuseums.

\section{SCIENTIFIC SERIALS}

THE Fournal of Anatomy and Physiology for April, I883, contains :-A contribution to the study of Spina bifida, encephalocele, and anencephalus, by Prof. Cleland (Plates II and 12).On the minute structure ol the palatine nerves of the frog, and the termination of nerves in blood-vessels and glands, by Prof. W. Stirling and J.F. Macdonald (Plate $\mathrm{r} 3$ ). - On the lymphatics of Periosteum, by Drs. George and F. Elizabeth Hoggan (Plate I4). - The brachial plexus of the macaque monkey, and its analogy with that of man, by W. T. Brooks.-A case of primary sarcoma of the pleura, by R. W. Greenish (Plate I5).-Infiltrating carcinoma of the breast, by Dr. G. Barling.-Observations of the diameters of human vertebræ in different regions, by Dr. R. J. Anderson.-On a simple form of Lippman's capillary electro. meter useful to physiologists, by Prof. McKendrick.-On socalled sponge-grafting, by Drs. K. Franks and P. S. Abraham (Plate I6).- The valvular action of the larynx, by Drs. T. L. Brunton and T. Cash.-Origin of the internal circumflex from the deep epigastric artery, by Dr. A. Thomson.-On cervical ribs and the so-called bicipital ribs in man in relation to the corresponding structures in the Cetacea, by Prof. Turner.-On a new form of ether microtome, by Dr. Cathcart.-On right-sided sigmoid flexure and rectum, by Dr. E. E. Maddox. $-\mathrm{A}$ note to Mr. Haswell's paper on myology of pigeon.

THE Quarterly Fournal of Microscopical Science for April, 1883, contains :- On the anatomy and development of Peripatus capensis, by the late Prof. F. M. Balfour, edited by Professors Moseley and Sedgwick (Plates I3 to 20). - On a morphological variety of Bacillus anthracis, by Dr. E. Klein, with notes thereon by Prof. Ray Lankester (Plate 21).-Note on a pink Torula, by $\mathrm{H}$. Marshall Ward (Plate 22). - On double staining nucleated blood corpuscles with anilin dyes, by Dr. V. Harris. Some recent researches on the continuity of the protoplasm through the walls of vegetable cells, by W. Gardiner.-Review of recent researches on Spermatogenesis, by J. E. Bloom. field. - Note on a minute point in the structure of the spermatozoon of the newt, by G. F. Dowdeswell.-On the existence of Spengel's olfactory organ and of paired genital ducts in the pearly nautilus, by Prof. Ray Lankester and A. G. Bourne.

\section{SOCIETIES AND ACADEMIES \\ LONDON}

Royal Society, April 12.- "On a New Crinoid from the Southern Sea." By P. Herbert Carpenter, M.A., Assistant Master at Eton College. Communicated by W. B. Carpenter, C.B., M.D., F.R.S.

Among the collections of the late Sir Wyville Thomson, a small Comatula has recently been discovered which was dredged by the Challenger at a depth of 1800 fathoms in the Southern Sea. Although it is unusually small, the diameter of the calyx being only $2 \mathrm{~mm}$., the characters presented by this form are such as to render it by far the most remarkable among all the types of recent Crinoids, whether stalked or free. The name proposed for it is Thaumatocrinus renovatus.

But it is distinguished by four striking peculiarities :-

(r.) The presence of a closed ring of basals upon the exterior of the calyx.

(2.) The persistence of the oral plates of the larva, as in Hyorinus and Rhizocrinus.

(3.) The separation of the primary radials by interradials which rest on the basals.

(4.) The presence of an arm-like appendage on the interradial plate of the anal side.

Taking these in order-

(r.) No adult Comatula, except the recent Atelecrinus and 